\title{
Factors influencing summer movement patterns of Bonneville cutthroat trout (Oncorhynchus clarkii utah)
}

\author{
Amy J. Schrank and Frank J. Rahel
}

\begin{abstract}
We used multiple approaches to study summer movement patterns of Bonneville cutthroat trout (Oncorhynchus clarkii utah) in the Thomas Fork drainage of western Wyoming, USA. Our objectives were to (i) document summer movement patterns of cutthroat trout, especially as related to the concepts of local turnover and displacement distances, (ii) determine if fish size and condition were related to mobility, and (iii) compare summer movement patterns between years. Large fish (270-384 mm total length) monitored by radiotelemetry showed little movement during the summer as evidenced by a maximum displacement distance of $<300 \mathrm{~m}$ and a low turnover rate among locations (0.21). For a broad size range of fish marked with visual implant tags (173-390 $\mathrm{mm}$ total length) in three study reaches, displacement distances were again low but turnover rate was high $(>0.50$ in most study reaches). This high turnover rate seemed to be driven mainly by movement among smaller fish as mobility declined with increasing fish size. Mobility also declined with decreasing body condition. Turnover rate in study reaches was higher during the summer of 1999 when stream flows were higher and water temperatures were cooler compared with the summer of 2000.

Résumé : Nous avons utilisé des approches multiples afin d'étudier les patrons estivaux de déplacement de la truite fardée de Bonneville (Oncorhynchus clarkii utah) dans le réseau hydrographique de la Thomas Fork dans l'Ouest du Wyoming, É.-U. Nos objectifs étaient $(i)$ de décrire les patrons estivaux de déplacement des truites fardées, en particulier en ce qui a trait aux concepts de remplacement local et de distance de déplacement, ( $i i)$ de voir si la taille et la condition des poissons sont reliées à la mobilité et (iii) de comparer les patrons estivaux de déplacement d'une année à l'autre. Les poissons plus grands (de longueur totale 270-384 mm) suivis par radio-télémétrie se déplacement peu pendant l'été, ce qui est confirmé par une distance maximale de déplacement de $<300 \mathrm{~m}$ et un faible taux de remplacement entre les sites $(0,21)$. Chez des poissons d'une gamme de tailles étendue et marqués avec des étiquettes de type implant visuel (de longueur totale 173-390 mm) dans trois sections d'étude, les distances de déplacement restent faibles, mais le taux de remplacement est élevé (>0,50 dans la plupart des sections). Ce fort taux de remplacement semble s'expliquer principalement par les déplacements des plus petits poissons, car la mobilité est fonction inverse de la taille des poissons. La mobilité décroît aussi proportionnellement au déclin de la condition. Le taux de remplacement dans les sections d'étude était plus élevé à l'été 1999 lorsque les débits étaient plus forts et les températures plus fraîches qu'à l'été 2000.
\end{abstract}

[Traduit par la Rédaction]

\section{Introduction}

Fish movement has important consequences for conservation and management of inland salmonid populations. Seasonal migrations among complementary habitats are required for fish to fulfill different life history requirements (Dunning et al. 1992; Schlosser 1995), and long-distance movements among spawning areas, summer feeding areas, and winter refuge areas have been demonstrated for salmonids (Brown and Mackay 1995; Schrank and Rahel 2004). Human-caused fragmentation of habitats has negative consequences for salmonid populations because it interrupts movement to and from these critical habitats and prevents fish from completing life histories (Rieman and Dunham 2000; Fausch et al. 2002). Less well understood is how human activities may affect fish movements over smaller temporal and spatial scales as fish seek habitats that maximize growth or reduce predation risk (Gowan and Fausch 2002).

An interesting issue for fish ecologists is the extent to which mobility patterns differ among fish species, among

Received 18 February 2005. Accepted 13 October 2005. Published on the NRC Research Press Web site at http://cjfas.nrc.ca on 15 February 2006.

J18567

A.J. Schrank ${ }^{\mathbf{1 , 2}}$ and F.J. Rahel. University of Wyoming, Department of Zoology and Physiology, Department 3166, 1000 E. University Avenue, Laramie, WY 82071, USA.

${ }^{1}$ Corresponding author (e-mail: ajschran@mtu.edu).

${ }^{2}$ Present address: School of Forest Resources and Environmental Science, Michigan Technological University, 1400 Townsend Drive, Houghton, MI 49931, USA. 
populations within a species, and even among size classes within a population (Gerking 1959; Gowan et al. 1994; Gowan and Fausch 1996a). Recently, much emphasis had been placed on the high degree of mobility evident in some populations of stream fishes (Gowan and Fausch 1996b; Kahler et al. 2001). However, Rodriguez (2002) has cautioned that although a high turnover rate of fish within a stream reach is often considered synonymous with high fish mobility, high turnover rate is also compatible with low displacement distances. Thus, there is a need to consider fish movement patterns in terms of both local turnover and the distances that fish move.

Why fish move during summer is not well understood. Movers may be subordinate fish unable to hold a territory (Jenkins 1969), fast-growing fish that have outgrown local food resources (Forseth et al. 1999; Morinville and Rasmussen 2003), fish in poor condition moving to seek increased food resources (Nordeng 1983; Gross et al. 1988; Mesick 1988), or fish moving to find better physical habitat conditions (Mesick 1988; Kahler et al. 2001; Gowan and Fausch 2002). In some situations, mobile fish tend to be longer in total length and lower in body condition than less mobile individuals (Naslund 1990; Gowan and Fausch 1996a; Hilderbrand and Kershner 2004). But in other situations, mobility declines with increasing fish size (Hughes 2000).

Determining how fish movement patterns change between years can provide insight into the reasons for movement. The relatively few studies that have examined year-to-year variation in fish movement patterns have emphasized spawning movements and fidelity to spawning sites (Swanberg 1997; Schmetterling 2001). Consequently, information about annual variation in summer movement patterns is limited (but see Hughes 2000). Relating fish movement patterns to abiotic conditions such as stream flow and water temperature would further our understanding of what causes year-toyear differences in fish mobility

The method by which fish movement is studied may influence our perception of mobility patterns (Gowan et al. 1994). For example, radiotelemetry studies, while enabling continuous study of the same individual, usually involve large fish because of concerns about how implanted transmitters may affect the behavior and swimming performance of small fish (Adams et al. 1998). Mark-recapture studies, while facilitating the study of a wide range of sizes, may be limited spatially and involve low sample sizes if recapture rates are low. To avoid these limitations, we used a combination of techniques involving radiotelemetry, mark-recapture of tagged fish, and weirs to examine movement across a large size range of fish present in our study population.

Understanding fish movement within a drainage basin is critical to predicting how human-caused changes to habitat and watershed connectivity will affect movement patterns and population persistence. This is particularly important for inland cutthroat trout throughout the western United States, as many populations have declined as a result of hybridization with nonnatives, habitat degradation, and fragmentation (Young 1995; US Fish and Wildlife Service 2001). Our study took place in the Thomas Fork drainage of Wyoming-Idaho, USA, which contains native populations of Bonneville cutthroat trout (Oncorhynchus clarkii utah) that are of conser- vation concern (Binns and Remmick 1994; Schrank et al. 2003).

Our study objectives were to $(i)$ document summer movement patterns of cutthroat trout in the Thomas Fork drainage, especially as related to the concepts of local turnover and displacement distances (Rodriguez 2002), (ii) determine if fish size and condition were related to fish mobility, and (iii) compare summer movement patterns between years to determine if the proportion of mobile fish changed with drought-related declines in streamflow.

\section{Materials and methods}

\section{Study site}

We studied Bonneville cutthroat trout movement in the upper portions of the Thomas Fork drainage of the Bear River in Lincoln County, Wyoming, and Bear Lake County, Idaho, USA (Fig. 1). Our study site included the Thomas Fork mainstem and three major tributaries: Huff, Little Muddy, and Coal creeks. Climate in this drainage consists of cold, snowy winters and hot, dry summers. Much of the watershed is heavily impacted by livestock grazing, and consequently, there is little riparian vegetation to shade the streams (Binns and Remmick 1994). Mean daily air temperature in summer (June-August) in the region is $15.1^{\circ} \mathrm{C}$ based on meteorological data from 1957-2001 for Afton, Wyoming, USA $\left(42^{\circ} 44^{\prime} \mathrm{N}, 110^{\circ} 56^{\prime} \mathrm{W}\right)$, approximately $40 \mathrm{~km}$ northwest of our study area (www.ncdc.noaa.gov/oa/ncdc.html). Our study took place in 1999 and 2000. Summer air temperatures were close to average during 1999 (mean daily air temperature of $15.5^{\circ} \mathrm{C}$ ) but were above average for 2000 (mean daily air temperature of $16.1{ }^{\circ} \mathrm{C}$ ). Water temperatures at the study reaches were higher in 2000 relative to 1999 (Fig. 2). Stream flows within $0.5 \mathrm{~km}$ of each study reach were lower in 2000 relative to 1999 (Fig. 2). Within the study area, there were no barriers to fish movement, and thus, fish were free to move among tributaries and the mainstem Thomas Fork.

\section{Objective I: document summer movement patterns of cutthroat trout}

We used three approaches to examine movement of Bonneville cutthroat trout within and between tributary streams and the Thomas Fork mainstem during the summers (June-August) of 1999 and 2000. These approaches allowed us to examine movement across a wide size range of fish and consisted of radiotelemetry, marking fish with visual implant (VI) tags (Haw et al. 1990), and use of two-way weirs to catch fish entering or leaving tributary streams.

\section{Radiotelemetry}

Between 24 June and 8 July 1999, 12 Bonneville cutthroat trout were captured by electrofishing at sites throughout Coal, Huff, and Little Muddy creeks (Fig. 1). Fish were anesthetized and a radiotransmitter weighing $2.9 \mathrm{~g}$ (Advanced Telemetry Systems, Isanti, Minnesota) was surgically implanted into the ventral body cavity of each fish, just anterior to the pelvic girdle (Adams et al. 1998). In all cases, the transmitter weight in air was $<2 \%$ of the body weight of the fish (Adams et al. 1998). Fish were ground tracked with an Advanced Telemetry Systems R2000 receiver operating at 
Fig. 1. Map of the Thomas Fork drainage of the Bear River in Lincoln County, Wyoming, and Bear Lake County, Idaho. Circles indicate the locations of 12 fish implanted with radiotransmitters and tracked during the summer of 1999. The displacement distances of these 12 fish did not exceed $300 \mathrm{~m}$. Numbers inside the circles indicate fish identification numbers as shown in Table 1. The location of weirs on Coal and Huff creeks and the locations of three study reaches where three-pass electrofishing was done are also shown.

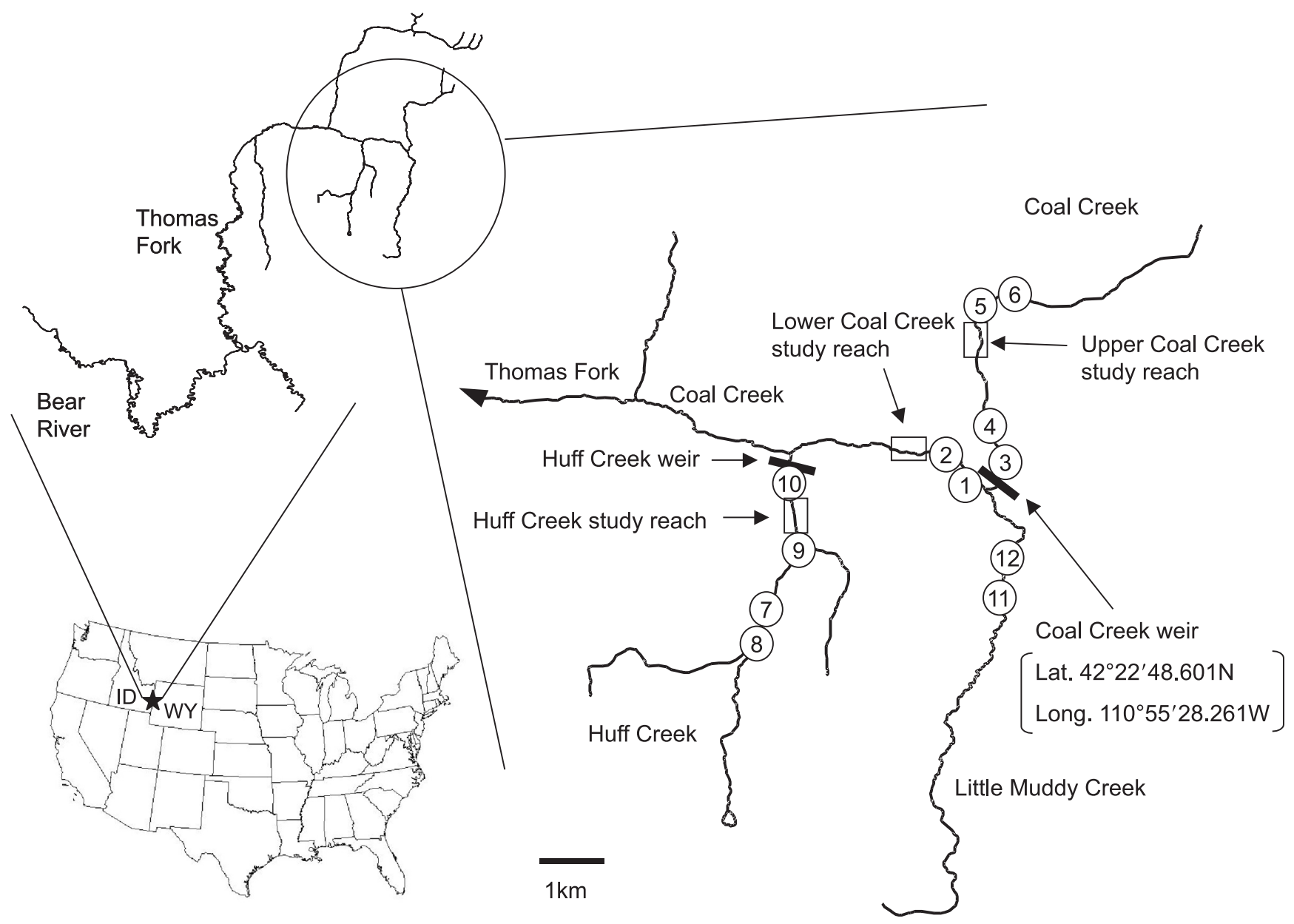

frequencies of 150.000-151.999 $\mathrm{MHz}$ and a four-element Yagi antenna. Fish were disturbed occasionally to determine if they were still alive. All fish were alive at the end of the tracking period. The 12 fish were located every other day throughout the summer from early July through mid-August. The average total length of these fish was $313 \mathrm{~mm}$ (range 270-384 mm) and average weight was 303 g (range 187$491 \mathrm{~g}$ ) (Table 1). Turnover rate was calculated as the proportion of time that fish were found in a location different from the previous location. Summer displacement distance for each radiotransmitter-implanted fish was determined as the total distance moved from the most upstream to the most downstream location.

\section{Weirs}

We installed two-way weirs in Coal and Huff creeks to monitor fish movement into and out of these tributaries. The weirs allowed us to determine if fish that were VI tagged in the three study reaches (described above) moved among tributaries. Furthermore, we implanted VI tags in all fish captured in the weirs to determine if these fish might later move into the three study reaches. Weir design followed Gowan and Fausch (1996b). Weirs included $0.5 \mathrm{~m}$ of skirting that was buried in the substrate or bank and then covered with sediment and rocks to ensure that fish were unable to escape around the weir. The Huff Creek weir was operated from 4 June through 22 August 1999. The Coal Creek weir was operated from 23 July through 22 August 1999. The weirs were monitored at least every other day to determine if fish were moving upstream or downstream. Fish captured in the weirs were measured, weighed, implanted with a VI tag, and released in the direction they were traveling. The weir was able to capture fish having a total length $\geq 150 \mathrm{~mm}$.

\section{VI tags}

During the summers of 1999 and 2000, we monitored the movement of fish into and out of three study reaches in Coal and Huff creeks that were representative of habitat throughout the tributaries (Fig. 1). The three study reaches were intensively electrofished (three-pass depletion with a backpack electrofisher) three times each summer in June, July, and August. Block nets were placed at the upstream and downstream ends of each study reach during electrofishing. Study reach length was $160 \mathrm{~m}$ in upper Coal Creek, $200 \mathrm{~m}$ in mid- 
Fig. 2. Stream discharge (left panels) and water temperature data (right panels) for (a) Huff Creek, (b) lower Coal Creek, and (c) upper Coal Creek. Solid circles are 1999 data; open circles are 2000 data.
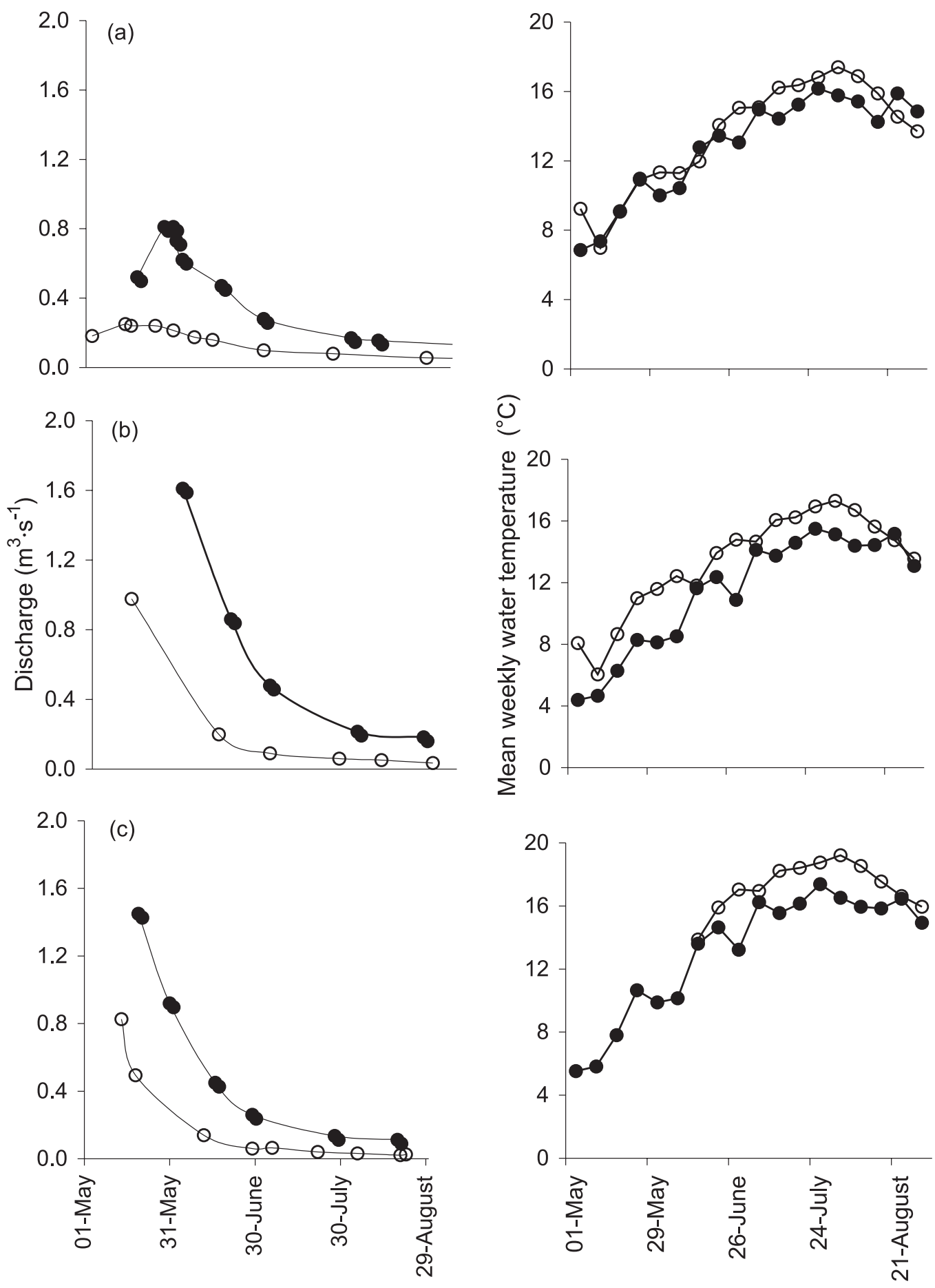

Date

dle Coal Creek, and $214 \mathrm{~m}$ in Huff Creek. During each sampling, all unmarked Bonneville cutthroat trout $>150 \mathrm{~mm}$ were marked with a unique alphanumeric VI tag (Haw et al. 1990), measured, weighed, and released in the same reach. A total of 151 fish were VI tagged in the three study reaches during the summers of 1999 and 2000. We also clipped the adipose fin of each VI tagged fish to monitor tag loss. All

fish captured that had been previously marked with a VI tag were also measured, weighed, and released. Fish that were marked with a VI tag and then recaptured in the same reach during the subsequent sampling period were considered recaptures, and fish $>150 \mathrm{~mm}$ captured in a reach without a VI tag or with a VI tag from another reach were considered immigrants. We also considered fish to be immigrants if they 
Table 1. Data for 12 fish that were implanted with radiotransmitters and tracked during summer 1999.

\begin{tabular}{|c|c|c|c|c|c|c|c|c|}
\hline $\begin{array}{l}\text { Fish } \\
\text { ID }\end{array}$ & $\begin{array}{l}\text { Original location of } \\
\text { capture and release }\end{array}$ & $\begin{array}{l}\text { Fish length } \\
(\mathrm{mm})\end{array}$ & $\begin{array}{l}\text { Fish weight } \\
(\mathrm{g})\end{array}$ & \multicolumn{2}{|c|}{ Tracking date } & $\begin{array}{l}\text { No. of times a } \\
\text { fish was located }\end{array}$ & $\begin{array}{l}\text { Displacement } \\
\text { distance }(\mathrm{m})\end{array}$ & $\begin{array}{l}\text { Turnover } \\
\text { rate }\end{array}$ \\
\hline 2 & Lower Coal Creek & 335 & 393 & 12 July & 18 Aug. & 13 & 100 & 0.25 \\
\hline 3 & Middle Coal Creek & 320 & 272 & 12 July & 19 Aug. & 14 & $<100$ & 0.25 \\
\hline 4 & Middle Coal Creek & 332 & 381 & 2 July & 17 Aug. & 13 & $<100$ & 0.00 \\
\hline 7 & Upper Huff Creek & 275 & 252 & 9 July & 19 Aug. & 13 & 100 & 0.36 \\
\hline 8 & Upper Huff Creek & 298 & 262 & 7 July & 19 Aug. & 15 & 300 & 0.40 \\
\hline 9 & Lower Huff Creek & 270 & 187 & 9 July & 18 Aug. & 13 & 300 & 0.08 \\
\hline 10 & Lower Huff Creek & 316 & 261 & 9 July & 18 Aug. & 13 & 200 & 0.18 \\
\hline 11 & Little Muddy Creek & 321 & 333 & 2 July & 19 Aug. & 17 & 100 & 0.31 \\
\hline
\end{tabular}

Note: Displacement distance indicates the distance from the most upstream to the most downstream location of a fish over the entire tracking period. Turnover rate was calculated as the proportion of time that a fish was found at a location that was different from its location on the previous tracking date.

had been tagged in a study reach, not captured for one or more sampling periods, but then recaptured in the study reach at a later date. These fish had probably moved out of the study reach and then returned. It is unlikely that they were present but missed during sampling because our capture efficiency was high (see Results: Objective I). During each sampling effort, numbers of recaptured and immigrant fish $(>150 \mathrm{~mm})$ were recorded.

We could use VI tags only on fish $>150 \mathrm{~mm}$ because fish below this size had poor tag retention. Therefore, it is possible that smaller fish could have grown enough to exceed $150 \mathrm{~mm}$ between sampling periods and thus been counted as unmarked fish when in reality they would have been present but too small to mark during the previous sampling period. To avoid this bias, we determined growth rate during the summer for fish captured at each study reach and eliminated fish during each sampling period that could have grown into the markable length category $(>150 \mathrm{~mm})$ since the last sampling effort (details in Schrank 2002). After eliminating these fish, we had 78 immigrant fish and 38 recaptured fish for our analysis.

To determine how frequently fish were moving in and out of the three study reaches, we calculated turnover rate during the July and August sampling periods in 1999 and 2000. Turnover rate was calculated as the 1 minus the proportion of marked individuals (Rodriguez 2002) in each reach during each sampling period.

\section{Objective II: determine if fish size and condition are related to mobility}

To determine if propensity to move into or out of a study reach was related to fish size, we compared total lengths of immigrant and recaptured fish among study reaches using a two-way ANOVA with movement status (recaptures or immigrants) and site as factors.

To determine if movement status was related to fish condition, we compared relative weights $\left(W_{\mathrm{r}}\right)$ for all immigrant and recaptured fish. The $W_{\mathrm{r}}$ was calculated based on the equation for standard weight for lotic cutthroat trout proposed by Kruse and Hubert (1997): $\log _{10}$ (standard weight $(\mathrm{g}))=-5.189+3.099 \log _{10}($ total length $(\mathrm{mm}))$. Of the 116 immigrant and recaptured fish, there was one fish for which a weight was not recorded; therefore, we used only 115 fish for this analysis. The $W_{\mathrm{r}}$ values were compared using a twoway ANOVA with movement status and site as factors. The Bonferroni procedure was used for post hoc comparisons among study reaches.

\section{Objective III: compare summer movement patterns between years}

To determine whether the turnover rate, and thus movement frequency, changed from 1999 to 2000, we calculated the mean difference between the turnover rate in 2000 and 1999 for the three study reaches. The data from July and August of a given year at a given site were pooled in this analysis. We then calculated a 95\% confidence interval around the mean difference in turnover rate. If this confidence interval did not include zero, it would indicate a difference in the turnover rate between the two years. A difference in turnover rate would, in turn, indicate a difference in movement tendencies between years.

\section{Results}

\section{Objective I: document summer movement patterns of cutthroat trout}

Radiotelemetry data indicated that large fish (range 270$384 \mathrm{~mm}$ total length, average $313 \mathrm{~mm}$ ) were not moving over long distances during the summer. The 12 fish implanted with radiotransmitters had displacement distances $\leq 300 \mathrm{~m}$ (Table 1; Fig. 1). Furthermore, average turnover rate was relatively low, at 0.21 , indicating that $79 \%$ of relocated individuals were within the same pool where they had been found on the previous tracking date (Table 1).

Catches in weirs also indicated little long-distance movement of Bonneville cutthroat trout. No fish moved upstream and four fish (range 181-266 mm total length, average $217 \mathrm{~mm}$ ) moved downstream through the Coal Creek weir during the 31 days that it was in operation. Seven fish moved upstream and 10 fish moved downstream through the Huff 
Table 2. Turnover rate of Bonneville cutthroat trout (Oncorhynchus clarkii utah) captured in three study reaches.

\begin{tabular}{llll}
\hline & \multicolumn{2}{l}{ Year } & \\
\cline { 2 - 3 } Study reach & 1999 & & $\begin{array}{l}\text { Difference in } \\
\text { turnover rate }^{a}\end{array}$ \\
\hline Huff Creek & $1.00(n=11)$ & $0.59(n=32)$ & 0.41 \\
Lower Coal Creek & $0.92(n=13)$ & $0.54(n=24)$ & 0.38 \\
Upper Coal Creek & $0.77(n=26)$ & $0.30(n=10)$ & 0.47 \\
\hline
\end{tabular}

Note: Turnover rate was calculated as 1 minus the proportion of marked individuals (Rodriguez 2002). The total number of fish collected in the sample reaches $(n)$ is given in parentheses.

${ }^{a}$ The mean difference in the turnorver rate between years 1999 and 2000.

Creek weir during the 79 days that it was in operation (range $193-410 \mathrm{~mm}$ total length, average $261 \mathrm{~mm}$ ). None of the fish given VI tags in the three study reaches were found in the weirs. Likewise, none of the fish given VI tags in the weirs were found in any of the study reaches. This suggests that fish moving out of the upper Coal Creek study reach did not move downstream more than $4.2 \mathrm{~km}$, which was the distance to the weir, and likewise, fish moving out of the Huff Creek study reach site did not move downstream more than $0.5 \mathrm{~km}$, the distance to the weir (Fig. 1). The weirs could catch fish as small as $150 \mathrm{~mm}$ total length, which indicates that the absence of long-distance movement observed in large fish using radiotelemetry was also true for smaller fish.

VI tagging data indicated that of the 116 fish used in our analysis, 78 were immigrants and 38 were recaptures (range 173-390 mm total length, average $226 \mathrm{~mm}$ ). Our tag loss rate was $1 \%$; therefore, it was unlikely that immigrants were fish that had lost their VI tag. Turnover rate was 0.5 or greater at all sites except in upper Coal Creek during 2000 (Table 2). Despite the high turnover rate in the study reaches, displacement distances were low, as VI tagged fish were never observed to move among the three study reaches, nor were they ever caught in the downstream weirs on Coal and Huff creeks.

We were confident that we captured most fish in a reach during a given sampling period because capture probabilities for each pass of the three-pass depletion electrofishing were high (capture probabilities were $>0.7$ for over $70 \%$ of the passes). Capture probabilities were calculated using the program Microfish 3.0 (Van Deventer and Platts 1989). Therefore, unmarked fish likely represented fish that had moved into the study reaches since the last sampling period rather than fish that had not been captured during the last sampling effort. Furthermore, to determine if movement in or out of study reaches was causing increases or decreases in populations over the summer, we also calculated abundance estimates and 95\% confidence intervals (for fish >150 mm) during each of the six sampling periods (Microfish 3.0; Van Deventer and Platts 1989). Abundance estimates showed no consistent increase or decrease throughout the summer, indicating that both emigration and immigration were occurring in the three study reaches (Schrank et al. 2003).

Another concern was whether the failure to recapture fish previously marked in a reach was due to mortality rather than emigration. There were 14 fish for which capture histories indicated that individuals were likely to be moving out of study reaches rather than experiencing mortality within them. Seven of these fish were initially given VI tags in one of the three study reaches, were subsequently absent from the reach, but then were recaptured in the same reach at a later time (fish Nos. 1-7 in Table 3). As an example, consider fish No. 4 that was initially captured and given a VI tag during preliminary sampling in lower Coal Creek in August of 1998. This fish was not present in the study reach in June 1999, was present in July 1999, was absent in August 1999, and was present in June 2000. This means that the absence of the fish in June 1999 and August 1999 was not due to mortality but to the fish having left that study reach. Because of other studies occurring in this drainage, fish were being marked at other sites within the watershed in addition to our three study reaches. As a result, five fish that were initially marked elsewhere were subsequently captured in one of the study reaches (fish Nos. 8-12 in Table 3) and two fish that were initially marked in one of the study reaches were subsequently captured elsewhere in the drainage (fish Nos. 13 and 14 in Table 3). For example, fish No. 10 was initially found upstream of the study reach in June of 1999 and was not found in the study reach in July and August of 1999 or June of 2000 but moved into the study reach and was captured there in July and August of 2000. These recapture histories provide evidence that some fish not recaptured in the study reaches were moving rather than dying.

\section{Objective II: determine if fish size and condition are related to mobility}

Fish that remained in the study reaches (recaptures) were significantly longer than immigrant fish (two-way ANOVA, df $=115, F=5.67, p=0.019, \alpha=0.05)$. Mean length \pm 1 SE was $239 \pm 7 \mathrm{~mm}$ for recaptured fish and $220 \pm 5 \mathrm{~mm}$ for immigrant fish. There was no interaction between site and movement status $(F=0.65, p=0.526)$ and no effect of site on fish length $(F=2.10, p=0.127)$.

Recaptured fish had significantly lower condition than immigrant fish as measured by $W_{\mathrm{r}}$ (two-way ANOVA, df = $114, F=10.03, p=0.002, \alpha=0.05)$. Mean $( \pm 1 \mathrm{SE}) W_{\mathrm{r}}$ across all sites for recaptured fish was $83.4 \pm 1.2$ and for immigrant fish was $88.1 \pm 0.9$. There was no interaction between movement status and site $(F=0.16, p=0.849)$. Mean $W_{\mathrm{r}}$ among study reaches differed $(F=9.25, p<0.001)$. Post hoc comparisons indicated that fish (immigrants and recaptures combined) from the upper Coal Creek site had a significantly higher average $W_{\mathrm{r}}( \pm 1 \mathrm{SE})(90.3 \pm 1.3)$ than fish from both lower Coal Creek $(82.9 \pm 1.3, p<0.001)$ and Huff Creek $(84.0 \pm 1.3, p=0.005)$. 
Table 3. Capture histories of 14 fish marked with VI tags in the Thomas Fork system.

\begin{tabular}{|c|c|c|c|c|c|c|c|c|}
\hline \multirow[b]{2}{*}{ Study reach } & \multirow[b]{2}{*}{ Fish ID } & \multicolumn{7}{|c|}{ Location status by date } \\
\hline & & Aug. 1998 & June 1999 & July 1999 & Aug. 1999 & June 2000 & July 2000 & Aug. 2000 \\
\hline \multicolumn{9}{|c|}{ Fish that were marked in a study reach, moved out of it, and then returned } \\
\hline Lower Coal Creek & 2 & + & $\square$ & $\square$ & + & $\square$ & $\square$ & $\square$ \\
\hline Lower Coal Creek & $3^{a}$ & + & + & + & $\square$ & $\square$ & $\square$ & $\square$ \\
\hline Lower Coal Creek & 4 & + & $\square$ & + & $\square$ & + & $\square$ & $\square$ \\
\hline Upper Coal Creek & 7 & + & $\square$ & $\square$ & + & $\square$ & $\square$ & $\square$ \\
\hline \multicolumn{9}{|c|}{ Fish that were marked outside a study reach and then moved into it } \\
\hline Huff Creek & 8 & NA & $\nabla$ & $\square$ & + & $\square$ & $\square$ & $\square$ \\
\hline Upper Coal Creek & 9 & NA & $\nabla$ & + & $\square$ & $\square$ & $\square$ & $\square$ \\
\hline Upper Coal Creek & 10 & NA & $\nabla$ & $\square$ & $\square$ & $\square$ & + & + \\
\hline \multicolumn{9}{|c|}{ Fish that were marked in a study reach and subsequently captured elsewhere } \\
\hline Huff Creek & $13^{b}$ & NA & + & $\square$ & $\square$ & $\square$ & $\square$ & $\square$ \\
\hline Upper Coal Creek & 14 & NA & + & $\square$ & $\square$ & $\nabla$ & $\square$ & $\square$ \\
\hline
\end{tabular}

Note: + indicates that a fish was captured within a study reach; $\square$ indicates that a fish previously captured in the study reach was absent from that reach during a subsequent sampling period; $\nabla$ indicates that a fish was captured elsewhere in the basin outside the three study reaches; NA, not available.

${ }^{a}$ Fish No. 3 was captured in the study reach during sampling for another study in October 1999.

${ }^{b}$ Fish No. 13 was captured outside the study reach during sampling for another study in October 1999.

\section{Objective III: compare summer movement patterns between years}

The turnover rate among the three study reaches was always higher in 1999 than in 2000 (Table 2). The mean difference in the turnover rate between years 1999 and 2000 was 0.42 and the $95 \%$ confidence interval for this difference did not include zero $(0.31<0.42<0.53)$. Therefore, turnover rate was substantially higher in 1999 than in 2000, indicating that fish were less mobile in 2000 (Table 2).

\section{Discussion}

Summer movement patterns of Bonneville cutthroat trout were characterized by low displacement distances and low turnover rates for large fish implanted with radiotransmitters (average total length $313 \mathrm{~mm}$ ) but low displacement distances and high turnover rates for a broader size range of fish implanted with VI tags (average total length $226 \mathrm{~mm}$ ). These results support the concept that fish mobility needs to be considered in terms of both attributes because high turnover at a local scale is compatible with relatively short movement distances (Rodriguez 2002). It is interesting to consider how our perception of mobility in fish populations is influenced by the interaction of turnover rate and movement distances. Turnover rate and displacement distance can be considered as axes that define a range of mobility types (Fig. 3). At one extreme are fish populations that show little mobility because few individuals leave a local site and those that do generally only move a short distance. Examples of such populations may be centrarchids in streams (Gerking 1959), fish with limited mobility such as sculpin (Petty and Grossman 2004), or the large Bonneville cutthroat trout implanted with radiotags in our study. At the other extreme are populations where most individuals are constantly moving
Fig. 3. Turnover rate and displacement distance can be considered as axes that define a range of mobility types. Traditionally, mobility has been viewed along a diagonal axis that confounds these factors. Low mobility was characterized as few individuals moving short distances, and high mobility was characterized as many individuals moving long distances. However, many stream salmonid populations seem to have many individuals (high turnover) moving over short distances (low displacement).

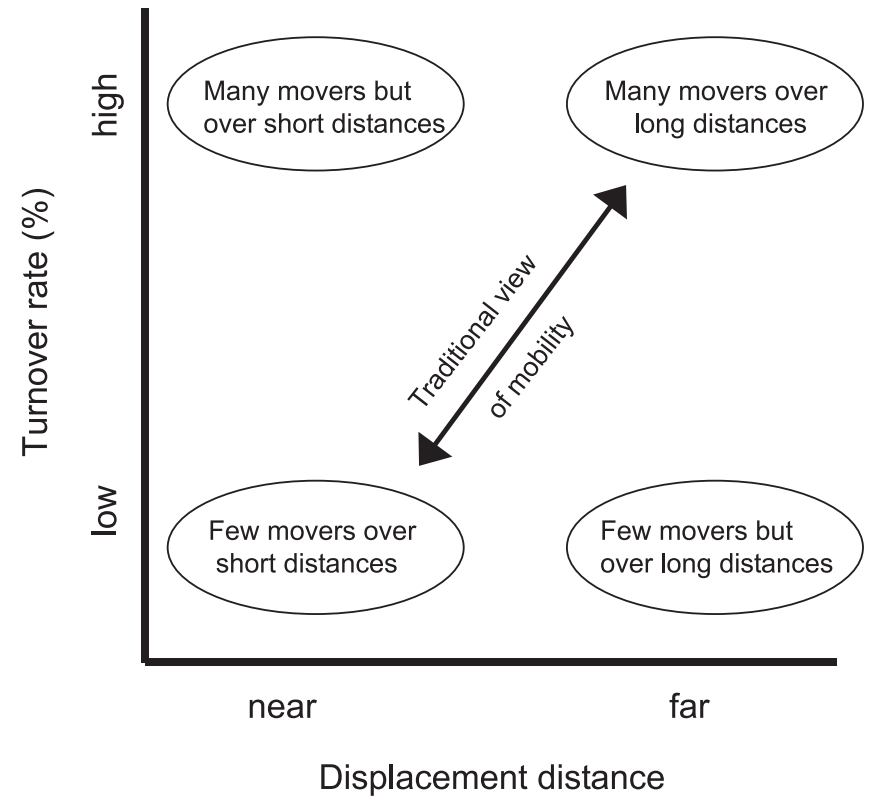

over large distances. Pelagic ocean predators such as tunas (Block et al. 2005) or bull trout in larger rivers (Swanberg 1997; Bahr and Shrimpton 2004) might be examples of highly mobile fish. Characterizing the mobility for other 
combinations of turnover and displacement distance is more difficult. Many inland populations of stream salmonids show a high turnover rate but low displacement distance such as that observed in the Bonneville cutthroat trout marked with VI tags in our study (Rodriguez 2002). Fish ecologists have tended to consider such populations as being highly mobile because the emphasis has been on turnover rate rather than how far fish actually move (Gowan and Fausch 1996a). It is difficult to think of fish populations that occupy the portion of mobility space characterized by low turnover but high displacement distances for the few individuals that do move. In terrestrial systems, examples would be highly territorial species such as cougars (Sweanor et al. 2000) or wolves (Gese and Mech 1991) where young are forced to disperse great distances to find unoccupied territories. A challenge for fish ecologists will be to consider how movement patterns for various species can be characterized in terms of both the proportion of individuals that leave a reach (i.e., turnover) and the average distances moved by such individuals (i.e., displacement distance).

High turnover but short movement distance is a common pattern for stream salmonids in summer (Gowan and Fausch 1996a; Hilderbrand and Kershner 2000; Rodriguez 2002). Such movement is best characterized as ranging behavior whereby organisms leave their current habitat and seek similar habitats with better resources in nearby areas (Dingle 1996). For salmonids, summer ranging behavior is thought to be associated with monitoring habitat conditions and maximizing foraging opportunities (Gowan and Fausch 2002). Stream salmonids often show increased local movements to meet increased metabolic demand as food resources are reduced (Fausch et al. 1997; Forseth et al. 1999; Morinville and Rasmussen 2003). The energetic profitability of stream locations varies with changes in streamflow and invertebrate drift (Gowan and Fausch 2002), which may explain why high turnover but low displacement distance is prevalent in drift-feeding stream salmonids.

In our study, the tendency to move declined with fish size as evidenced by the frequency with which radiotransmitterimplanted fish were detected in the same pools throughout the summer (low turnover rate) and by the fact that for VI tagged fish, recaptures were significantly larger than immigrants $(p=0.019)$. Hughes (2000) suggested that because larger fish generally occupy the most energetically profitable locations in a stream, they should move least and his data on movement of Artic grayling (Thymallus arcticus) ranging from 150 to $410 \mathrm{~mm}$ total length supported this hypothesis. This does not seem to be the case for Bonneville cutthroat trout in the Thomas Fork. Fish that did not move between periods were in poorer condition than fish that moved. This does not support the idea that large fish were simply staying put in energetically profitable locations. Tributaries to the Thomas Fork tend to have few deep pools in the summer, at least partly because past livestock grazing has reduced riparian vegetation, increased erosion, and reduced bank stability (Binns 1981; Binns and Remmick 1994). Therefore, large cutthroat trout may have fewer habitat options and tend to remain in the few large pools that are present even if food levels decline. Supporting the idea that large fish were severely habitat limited in the Thomas Fork is the observation that turnover rate within study reaches was lower in 2000 than in 1999 in association with lower stream flow. This decrease in flow would have the effect of reducing habitat for larger fish as the number and depths of pools declined, restricting fish movement even further.

We found that large cutthroat trout tended to be located in the same pool throughout the radiotelemetry study, but we only located fish during the day. We do not know the extent to which large Bonneville cutthroat trout may make nocturnal ranging movements to explore habitat conditions in other areas of a stream. However, Young et al. (1997) reported that another subspecies, Colorado River cutthroat trout (Oncorhynchus clarkii pleuriticus), was largely inactive at night. More work is needed to understand how stream salmonids assess the quality of habitat conditions in other areas of the stream.

Water temperature is another factor that could influence movement patterns. In some cases, salmonids move to coldwater refuge areas when remaining areas of a stream become too warm (Berman and Quinn 1991; Li et al. 1994; Nielsen et al. 1994). However, in the Thomas Fork drainage, Bonneville cutthroat trout remain in tributaries during the summer even when daytime water temperatures reach $27{ }^{\circ} \mathrm{C}$ (Schrank et al. 2003). The short duration of these high water temperatures, which last only a few hours during each diel cycle, may allow fish to tolerate them until thermal conditions improve (Johnstone and Rahel 2003; Schrank et al. 2003).

The lack of movement by larger fish in this watershed suggests that an effective management action would be a restoration of habitat to increase pools. Historically in these tributaries, beaver ponds were common and likely provided pool habitat for large fish; however, with increases in grazing and an absence of willows, beaver are less common (Binns 1981). Binns and Remmick (1994) examined Bonneville cutthroat trout populations before and after habitat improvement on Huff Creek. They found that large cutthroat trout $(>15 \mathrm{~cm})$ increased from 22 trout $\cdot \mathrm{km}^{-1}$ before habitat improvement to 106 trout $\cdot \mathrm{km}^{-1} 11$ years after habitat improvement. This suggests that habitat limits the abundance of large fish in the tributaries and this would be especially true in dry years.

Movement studies often employ a single method to examine fish movement and this can affect the conclusions drawn from these studies when the size of fish studied is limited by the method used. For example, studies that use radiotelemetry can only monitor movements of fish large enough to accommodate implantation of transmitters (Adams et al. 1998). Thus, movement by smaller fish needs to be assessed by other techniques. We examined movement patterns of relatively large fish $(>275 \mathrm{~mm})$ with radiotelemetry and relatively small fish $(>150 \mathrm{~mm})$ using VI tags and weirs. If we had only used radiotelemetry, we might have concluded that Bonneville cutthroat trout moved little during the summer (low turnover rate) and often resided in the same pool for extended periods. However, if we had only used VI tag recapture data, we would have concluded that Bonneville cutthroat trout moved frequently because turnover rate was high.

Using multiple approaches to study movement provided a more complete picture of the movement patterns of Bonneville cutthroat trout in the Thomas Fork system. A proportion of the adult population undergoes extensive migrations in the spring to headwater tributaries to spawn and then back 
to mainstem reaches to spend the summer (Schrank and Rahel 2004). The relatively few large fish that remain in the tributaries show little movement throughout the remainder of the summer, often residing in the same pool for extended periods. Smaller fish show frequent local movement during the summer with high turnover within a reach but have low displacement distances and tend to remain within the tributary streams. This size difference in summer movement patterns probably reflects a greater habitat limitation for large fish relative to small fish. Future studies will benefit from considering turnover and displacement as distinct aspects of fish movement as we attempt to understand the reasons for the diversity of movement patterns evident in stream fishes. A focus on understanding the extent, timing, and causes of movement across the size range of fish in a population will allow researchers to better predict how human changes to a watershed, such as habitat degradation, fragmentation, and water diversion, will affect movement patterns and population persistence.

\section{Acknowledgements}

We thank Helene Johnstone, Ronald Remmick, Paul Dey, Joseph Bump, Vern Phinney, Seth White, Roy Martin, and Robert Hall for their assistance in this research. Kurt Fausch, Wayne Hubert, Jeffrey Lockwood, Dirk Miller, and three anonymous reviewers provided helpful review of the manuscript. Funding was provided by the Wyoming Game and Fish Department, the Department of Zoology and Physiology of the University of Wyoming, and a J. Frances Allen Scholarship from the American Fisheries Society to A.J. Schrank.

\section{References}

Adams, N.S., Rondorf, D.W., Evans, S.D., and Kelly, J.E. 1998. Effects of surgically and gastrically implanted radio transmitters on growth and feeding behavior of juvenile chinook salmon. Trans. Am. Fish. Soc. 127: 128-136.

Bahr, M.A., and Shrimpton, J.M. 2004. Spatial and quantitative patterns of movement in large bull trout (Salvelinus confluentus) from a watershed in north-western British Columbia, Canada, are due to habitat selection and not differences in life history. Ecol. Freshw. Fish, 13: 294-304.

Berman, C.H., and Quinn, T.P. 1991. Behavioral thermoregulation and homing by spring chinook salmon, Oncorhynchus tshawytscha (Walbaum), in the Yakima River. J. Fish Biol. 39: 301-312.

Binns, N.A. 1981. Bonneville cutthroat trout, Salmo clarki utah, in Wyoming. Wyoming Game and Fish Department, Cheyenne, Wyo. Fish. Tech. Bull. 5.

Binns, N.A., and Remmick, R. 1994. Response of Bonneville cutthroat trout and their habitat to drainage-wide habitat management at Huff Creek, Wyoming. N. Am. J. Fish. Manag. 14: 669-680.

Block, B.A., Boustany, A., Dewar, H., Farwell, C.J., Stokesbury, M.J.W., Teo, S.L.H., Walli, A., Weng, K.C., and Williams, T.D. 2005. Electronic tagging and population structure of Atlantic bluefin tuna. Nature (London), 434: 1121-1127.

Brown, R.S., and Mackay, W.C. 1995. Fall and winter movements of and habitat use by cutthroat trout in the Ram River, Alberta. Trans. Am. Fish. Soc. 124: 873-885.

Dingle, H. 1996. Migration: the biology of life on the move. Oxford University Press, Oxford, UK.
Dunning, J.B., Danielson, B.J., and Pulliam, H.R. 1992. Ecological processes that affect populations in complex landscapes. Oikos, 65: $169-175$.

Fausch, K.D., Nakano, S., and Kitano, S. 1997. Experimentally induced foraging mode shift by sympatric charrs in a Japanese mountain stream. Behav. Ecol. 4: 414-420.

Fausch, K.D., Torgersen, C.E., Baxter, C.V., and Li, H.W. 2002. Landscapes to riverscapes: bridging the gap between research and conservation of stream fishes. Bioscience, 52: 483-498.

Forseth, T., Naesje, T.F., Jonsson, B., and Harsaker, K. 1999. Juvenile migration in brown trout: a consequence of energetic state. J. Anim. Ecol. 68: 783-793.

Gerking, S.D. 1959. The restricted movement of fish populations. Biol. Rev. 34: 221-242.

Gese, E.M., and Mech, L.D. 1991. Dispersal of wolves (Canis lupus) in northeastern Minnesota, 1969-1989. Can. J. Zool. 69: 2946-2955.

Gowan, C., and Fausch, K.D. 1996a. Mobile brook trout in two high elevation Colorado streams: re-evaluating the concept of restricted movement. Can. J. Fish. Aquat. Sci. 53: 1370-1381.

Gowan, C., and Fausch, K.D. 1996b. Long-term demographic responses of trout populations to habitat manipulation in six Colorado streams. Ecol. Appl. 6: 931-946.

Gowan, C., and Fausch, K.D. 2002. Why do foraging stream salmonids move during the summer? Environ. Biol. Fishes, 64: 139-153.

Gowan, C., Young, M.K., Fausch, K.D., and Riley, S.C. 1994. Restricted movement in resident stream salmonids: a paradigm lost? Can. J. Fish. Aquat. Sci. 51: 2626-2637.

Gross, M.R., Coleman, R.M., and McDowall, R.M. 1988. Aquatic productivity and the evolution of diadromous fish migration. Science (Washington, D.C.), 239: 1291-1293.

Haw, F., Bergman, P.K., Fralick, R.D., Buckley, R.M., and Blankenship, H.L. 1990. Visible implanted fish tag. Am. Fish. Soc. Symp. 7: 127-133.

Hilderbrand, R.H., and Kershner, J.L. 2000. Movement patterns of stream-resident cutthroat trout in Beaver Creek, Idaho-Utah. Trans. Am. Fish. Soc. 129: 1160-1170.

Hilderbrand, R.H., and Kershner, J.L. 2004. Are there differences in growth and condition between mobile and resident cutthroat trout? Trans. Am. Fish. Soc. 133: 1042-1046.

Hughes, N.F. 2000. Testing the ability of habitat selection theory to predict interannual movement patterns of a drift-feeding salmonid. Ecol. Freshw. Fish, 9: 4-8.

Jenkins, T.M. 1969. Social structure, position choice and microdistribution of two trout species (Salmo trutta and Salmo gairdneri) resident in mountain streams. Anim. Behav. Monogr. 2: 57-122.

Johnstone, H.C., and Rahel, F.J. 2003. Assessing temperature tolerance of Bonneville cutthroat trout based on constant and cycling thermal regimes. Trans. Am. Fish. Soc. 132: 92-99.

Kahler, T.H., Roni, P., and Quinn, T.P. 2001. Summer movement and growth of juvenile anadromous salmonids in small western Washington streams. Can. J. Fish. Aquat. Sci. 58: 1947-1956.

Kruse, C.G., and Hubert, W.A. 1997. Proposed standard weight $\left(W_{s}\right)$ equations for interior cutthroat trout. N. Am. J. Fish. Manag. 17: 784-790.

Li, H.W., Lamberti, G.A., Pearsons, T.N., Tait, C.K., Li, J.L., and Buckhouse, J.C. 1994. Cumulative effects of riparian disturbance along high desert trout streams of the John Day Basin, Oregon. Trans. Am. Fish. Soc. 123: 627-640.

Mesick, C.F. 1988. Effects of food and cover on numbers of Apache and brown trout establishing residency in artificial stream channels. Trans. Am. Fish. Soc. 117: 421-431. 
Morinville, G.R., and Rasmussen, J.B. 2003. Early juvenile bioenergetic differences between anadromous and resident brook trout (Salvelinus fontinalis). Can. J. Fish. Aquat. Sci. 60: 401-410.

Naslund, H. 1990. The development of regular seasonal habitat shifts in a landlocked Arctic charr, Salvelinus alpinus L., population. J. Fish Biol. 36: 401-414.

Nielsen, J.L., Lisle, T.E., and Ozarki, V. 1994. Thermally stratified pools and their use by steelhead in northern California streams. Trans. Am. Fish. Soc. 123: 613-626.

Nordeng, H. 1983. Solution to the "char problem" based on Arctic char (Salvelinus alpinus) in Norway. Can. J. Fish. Aquat. Sci. 40: 1372-1387.

Petty, J.T., and Grossman, G.D. 2004. Restricted movement by mottled sculpin (Pisces: Cottidae) in a southern Appalachian stream. Freshw. Biol. 49: 631-645.

Rieman, B.E., and Dunham, J.B. 2000. Metapopulations and salmonids: a synthesis of life history patterns and empirical observations. Ecol. Freshw. Fish, 9: 51-64.

Rodriguez, M.A. 2002. Restricted movement in stream fish: the paradigm is incomplete, not lost. Ecology, 83: 1-13.

Schlosser, I.J. 1995. Critical landscape attributes that influence fish population dynamics in headwater streams. Hydrobiolgia, 303: 71-81.

Schmetterling, D. 2001. Seasonal movements of fluvial westslope cutthroat trout in the Blackfoot River drainage, Montana. N. Am. J. Fish. Manag. 21: 507-520.

Schrank, A.J. 2002. Ecological significance of movement patterns of Bonneville cutthroat trout in a western Wyoming watershed. Ph.D. thesis, University of Wyoming, Laramie, Wyo.
Schrank, A.J., and Rahel, F.J. 2004. Movement patterns in inland cutthroat trout (Oncorhynchus clarki utah): management and conservation implications. Can. J. Fish. Aquat. Sci. 61: 1528-1537.

Schrank, A.J., Rahel, F.J., and Johnstone, H.C. 2003. Evaluating laboratory-derived thermal criteria in the field: an example involving Bonneville cutthroat trout. Trans. Am. Fish. Soc. 132: 100-109.

Swanberg, T.R. 1997. Movements of and habitat use by fluvial bull trout in the Blackfoot River, Montana. Trans. Am. Fish. Soc. 126: $735-746$.

Sweanor, L.L., Logan, K.A., and Hornocker, M.G. 2000. Cougar dispersal patterns, metapopulation dynamics, and conservation. Conserv. Biol. 14: 798-808.

US Fish and Wildlife Service. 2001. 12-month finding for a petition to list the Bonneville cutthroat trout as threatened throughout its range. Federal Register, 66: 51362-51366.

Van Deventer, J.S., and Platts, W.S. 1989. Microcomputer software system for generating population statistics from electrofishing data - user's guide for MicroFish 3.0. Forestry Sciences Laboratory, Intermountain Research Station, Boise, Idaho.

Young, M.K. 1995. Conservation assessment for inland cutthroat trout. US Dep. Agric. For. Serv. Rocky Mt. Exp. Stn. Gen. Tech. Rep. RM-256.

Young, M.K., Rader, R.B., and Belish, T.A. 1997. Influence of macroinvertebrate drift and light on the activity and movement of Colorado River cutthroat trout. Trans. Am. Fish. Soc. 126: 428-437. 